\title{
CLEC4C wt Allele
}

National Cancer Institute

\section{Source}

National Cancer Institute. CLEC4C wt Allele. NCI Thesaurus. Code C104132.

Human CLEC4C wild-type allele is located within 12p13.2-p12.3 and is approximately 22 $\mathrm{kb}$ in length. This allele, which encodes c-type lectin domain family 4 member $\mathrm{C}$ protein, plays a role in antigen processing and presentation. 